\title{
Mobilidade urbana e cidadania no Distrito Federal: um estudo do Programa Brasília Integrada
}

Diego Lourenço Carvalho

Curso: Mestrado em Sociologia

Data da defesa: 16 de junho de 2008

Orientadora: Prof ${ }^{\mathrm{a}}$. Dr ${ }^{\mathrm{a}}$. Maria Salete Kern Machado

\section{Resumo}

Esta dissertação tem como tema a relação entre a mobilidade urbana e a cidadania no Distrito Federal, com enfoque nas atuais condições de deslocamento da população e nas perspectivas trazidas pelo Programa Brasília Integrada.

O objetivo é, a partir de um olhar sociológico, analisar o trânsito da cidade, considerando a acepção mais completa do termo, que envolve todas as formas de locomoção. Para isso, realizou-se uma revisão bibliográfica em que se buscou, nos textos clássicos de sociologia urbana e em obras mais recentes, a fundamentação teórica da importância da mobilidade para a existência e o desenvolvimento das cidades e do modo de vida urbano.

$\mathrm{Na}$ descrição e análise da mobilidade urbana do Distrito Federal, chega-se à conclusão de que, devido à prioridade ter sido, até hoje, o deslocamento por automóveis particulares, a situação é crítica para todos os atores do trânsito (motoristas, pedestres, ciclistas e usuários de transporte público) e tende a piorar, podendo chegar ao colapso, caso não sejam adotadas medidas urgentes para reverter essa tendência. 
As formas como a cidade foi planejada e como o poder público conduziu sua política de mobilidade urbana consolidaram uma "cultura do automóvel" e um ciclo vicioso de aumento do número de carros seguido de mais investimentos na estrutura viária, deixando o transporte público em segundo plano e destinado apenas a atender as necessidades de acesso aos locais de trabalho das classes menos abastadas.

A principal aposta do governo do Distrito Federal para solucionar os problemas de locomoção da capital federal, constituída pelo Programa Brasília Integrada, prevê a reformulação do sistema de transporte público coletivo da cidade, além da construção de ciclovias e da ampliação da malha viária.

Conclui-se que, apesar de positivas as ações previstas no Programa, elas serão insuficientes para evitar o colapso no trânsito de Brasília. Seria necessária uma mudança de paradigmas da política de mobilidade urbana, colocando como prioridade as formas sustentáveis de locomoção, em especial, o transporte público coletivo, de forma a superar a "cultura do automóvel" ainda vigente na mentalidade da população e do governo locais.

Palavras-chave: mobilidade urbana; trânsito; Brasília Integrada; Distrito Federal. 